\title{
A Small Place in Between: Caryl Phillips's A State of Independence
}

Claude Julien

\section{(2) OpenEdition \\ 1 Journals}

Electronic version

URL: https://journals.openedition.org/ces/4486

DOI: $10.4000 /$ ces.4486

ISSN: 2534-6695

Publisher

SEPC (Société d'études des pays du Commonwealth)

\section{Printed version}

Date of publication: 1 September 2017

Number of pages: $71-80$

ISSN: 2270-0633

\section{Electronic reference}

Claude Julien, "A Small Place in Between: Caryl Phillips's A State of Independence", Commonwealth Essays and Studies [Online], 40.1 | 2017, Online since 02 April 2021, connection on 24 January 2022 URL: http://journals.openedition.org/ces/4486 ; DOI: https://doi.org/10.4000/ces.4486

\section{(c) $($ †) $\ominus$}

Commonwealth Essays and Studies is licensed under a Licence Creative Commons Attribution - Pas d'Utilisation Commerciale - Pas de Modification 4.0 International. 


\section{A Small Place in Between: Caryl Phillips's $A$ State of Independence}

This article looks at Caryl Phillips's second novel, A State of Independence, from the perspective of the different forms of independence which might be detected in the title.

Analysed in the light of the speech by Marcus Garvey quoted in the epigraph, it can be seen as a chronicle of the islanders' incapacity to live up to Garvey's ideal. From an existential point of view, the isolation of the characters like Bertram, the returning islander, who is unable to build an existence founded on relationships with others, can be seen as a metaphor for the island itself, caught between two times and two places, Great Britain and America, the colonial past and the era of American domination.

Stories are like onions. You peel one skin and another grins up at you.

John E. Wideman, Fatheralong

The form of A State of Independence ${ }^{1}$ is unique in Caryl Phillips's œuvre. While Crossing the River, for instance, places different characters in interdependent stories, spans centuries and moves from one locale to the next, A State of Independence is fully linear. Indeed, it almost conforms to the rigid rules of the three unities which informed classical plays. There is one location (the island - prison like) and one story line, strictly concerned with Bertram's education. The unity of time is warped to suit a story unfolding over three days only; or three acts divided into eleven scenes ${ }^{2}$ separated by the weakest of markers, two blank lines. The events and thoughts in this relentless sweep are described, in no way commented upon, by an omniscient narrator.

The book's title is intriguing, slightly off-center linguistically. ${ }^{3}$ The word independence apposed to state through the preposition of raises questions: whose or what state and whose or what independence are to be spoken about? By quoting a blurb from The Observer, "Spirit and dash here return to the political novel," the book's cover is complicit in the temptation to read the novel as a story based on local politics. So is the illustration, with festive bunting hanging from wires over a fairly affluent cement home in the foreground contrasting with a boarded cabin further down the black top road. A breadfruit tree, the poor man's nourishment, overhangs that home. The landscape

1. All references will be to the original 1986 Faber edition.

2. These follow Bertram's actions or the people he comes across. Scene after scene form a chain-like progression: pages 11-27 describe his homecoming, then 27-48 take him into his former home where memories of the years prior to his departure assail him, 48-52 is his confrontation with his mother, pages 52-69 take him to town and his first meeting, almost friendly, with Jackson Clayton, 69-87 mostly deal with his early companionship with his brother and their growing distance from each other, 87-94 describe his going to Patsy's home, 94-101 deal with memories of his breaking off with Patsy twenty years before, 101-119 see him in the capital again where Jackson tells him there is no room for him on the island and threatens to make his business fail, 119-139 take him to the showy and artificial tourist-oriented area, 139153 see him in Patsy's home again, with the perspective of a possible future together, 153-158 describe the boisterous independence celebration and conclude on Bertram's irresolution as he walks back home.

3. Bénédicte Ledent points out that Phillips's themes show how "black music was a source of inspiration for the young writer [...]" (7). "State of Independence" (1981) became a major hit sung by Donna Summer. The song's lyrics have little in common with Phillips's novel apart from their bringing up the Caribbean and third world countries. However, the song's title may have inspired the novelist's choice for a title.

4. The newspaper's full name is The St. Kitts-Nevis Observer. 
is deserted and no boat is moored to the pier at the far end, which suggests a lack of communication. ${ }^{5}$

The novel's pessimistic politics were not well received in Saint Kitts, as we shall see later when the text focuses on Bertram's impression of a persisting rural poverty, or when Lonnie lists every thing that goes wrong, or again as an uncertain (both personal and national) future hovers over the last few words. Phillips most likely had no hand in the blurb on the book's cover that classifies the novel as "political." But the four opening epigraphs (page vii) add up to a paratext prefacing the story which encourages that kind of construct as one prepares to read on. This paratext is composed of a passage reshuffled from Marcus Garvey's 1937 speech exhorting Kittitians to take their island in their own hands, followed by two polemical journalistic excerpts exposing drunken or profiteering local politicians. Finally comes an excerpt from the book itself extolling a better future under the wings of the American eagle.

As the quotation from John Wideman's Fatheralong ${ }^{6}$ suggests, any story will offer more than one door. Local politics are not the only angle from which to approach $A$ State of Independence. Curiosity, aroused by reading the full text of the address Garvey delivered, leads to another route into the book, aside from the politics of independence. Indeed, the leader of the Universal Negro Improvement Association insisted on God's plan - equality - and the state of mind the islanders must cultivate to rise in life and make their island the Black Eden it should be. Educating one's mind is the root of his insistence on self-help and the way to ethnic entrepreneurship:

Those who are up think upward, and those who are down think downward. God has nothing to do with it. As our thoughts are so do we appear, whether clean or ragged. God made your soul equal with that of the prince or the peasant. [...] Man is a product of his mind. If you do not train and protect your mind, men with trained minds will subjugate you. People only liberate themselves through their state of mind. (Hill 805) ${ }^{7}$

This quotation may be a key to the novel. Indeed, Bertram's only wish and hope (dream may be a better word) is to create his own business in order to become independent from the white man. If approached from that angle, A State of Independence reaches beyond the island's independence from colonial power to possibly become a commentary upon Garvey's philosophy: either denouncing it as illusion-ridden, ${ }^{8}$ or else, blaming the characters for failing to abide by his recommendations.

Before we turn back to Garvey's 1937 speech, we will contextualize the novel briefly in order to bring up the island's recent past and severance from colonial dependence. Saint Kitts was part of the Leeward Islands Federation until the West Indies Federation associated it with Nevis and Anguilla in a separate state from 1958 to 1962. The federa-

5. The pier, a useless attempt to facilitate trade, "a finger pointed nowhere" (58), is a significant element in this respect. Dots between the arches on the book's cover may represent small fishing boats.

6. This portmanteau word reads like further along.

7. Garvey first spoke up for "African fundamentalism" in Jamaica and London before Booker T. Washington encouraged him to come to the USA. He toured the US in 1916, speaking to raise funds to open a Tuskegee-like school in Jamaica. This project never was brought to completion. Garvey is mostly known for his failed back-to-Africa movement but floated other equally unsuccessful schemes, such as the Negro Factories Corporation whose ambition was to manufacture marketable commodities in US ethnic neighborhoods, Central America, the Caribbean and Africa.

8. In 1937, the UNIA was a survivor. Garvey's bold schemes collapsed or never took wing. He pursued his ideals but his following was nowhere near the 4,000,000 plus members the UNIA claimed in its heyday. Even then, many criticized Garvey's imperious ways. His relationship with Du Bois who called his rhetoric "bombastic and impracticable" (Franklin 321) was especially acrimonious. 
tion's status changed when it became an Associated State of Britain in 1967. However, that same year, Anguilla attempted a secession which brought colonial troops to restore order. The coup d'état failed, but Anguilla eventually secured its independence in 1971. These troubled events are very briefly alluded to in A State of Independence, described like an operetta buffoonery that speaks volumes on the bitterness of being a negligible quantity: 6,000 Red Berets invaded the rebel island, "barely six miles long" (21), where the three policemen only had two rifles to share between them. But the text is silent on the creation of a federation comprising Saint Kitts and Nevis on Independence Day, an event of definite political importance. Instead, there only is an allusion to "the sole surviving sister island" (56), seen in the distance, fragile, seemingly suspended to a canopy of clouds, and above all nameless. The result of that omission is that Saint Kitts appears singular in the novel, unattached. Independence and solitude may combine into a metaphor creating another fictional strand - existential - in a story whose characters appear self-centered, lack the sense of solidarity or are, like Bertram and Dominic, unable to durably establish companionship, let alone, like Bertram and Patsy, a couple based on a real relationship.

Forgetting about independence per se we will first explore the novel from the perspective of a story taking issue with Garvey's dichotomous world. Secondly we will move on to suggestions of an existential level - states of mind conditioned by the island.

Garvey visited Saint Kitts on returning from a tour that took him as far down as British Guiana. His address drew a large crowd in the hall of the Mutual Improvement Society where he expatiated with passion on his self-given duty to bring hope and confidence to people like himself, born dispossessed, his wish to kindle in black people the desire and energy to rise above their situation as he himself did when he left Jamaica.

"The success ideal was central to Garvey's racial perspective, and the ideology of the American cult of success exerted a profound influence on the evolution of his program for racial independence," Hill writes before discussing Garvey's "religion of success" (xli). Garvey saw men as individuals devoted to their particular interest: "But when it comes to your individual lives, 'fix yourselves up' or somebody may want to make monkeys out of you. Even two sisters in the same house try to outdo each other... whatever you want in the world... go after it yourself." (Hill 807)

True to his well-honed line, he argued that men must take the blame for their situation and failings. A typically American social Darwinist stance suffuses the address. ${ }^{9}$ Those who have failed simply did not have the stamina it takes to succeed. With grit, they would have striven to partake of God's universal intelligence and worked their way up, building a better society. There is no better world beyond the grave. The good life is to be culled here and now. Being a go-getter is the only way to personal success and countering one's fellow men's selfishness. Garvey remonstrates against lame ducks who produce nothing at all. Contemptuous and peremptory, he argues such men are of more use dead because, when buried, "they produce manure, so that nothing is lost" (Hill 807).

He recommends thinking before acting, going beyond elementary schooling, educating one's mind and spending "a little less on food and a little more on [one's] brain"

9. Garvey was a self-made man, abrasively proud of his success. After launching his soon abandoned Liberia program in 1920, some charged he wanted to take all African Americans back home. He countered: "We do not want all the Negroes in Africa. Some are no good here, and naturally will be no good there” (Jacques122). 
(Hill 809). His address closes on the matter of size. Small as their island is, Kittitians must "try to make [it] the best spot in the world" (Hill 810). Effort is the word of the day. Perhaps recalling the labor riots of 1935-1936, he urges people to get "hold of the land" as "[t]he men who hold the land make the laws" (ibid.). That the spokesman for the poor does not mention the over one-year-long unrest seems strange. ${ }^{10}$ The crisis of course arose from the collapse of sugar prices; sugar, the "vast economic blight" ( $A$ State of Independence 17) peppering the countryside Bertram sees: abandoned mills and decayed great houses seen from the sky or, while walking home after the independence celebration, "discreet reminders of a troubled and bloody history" (157).

The novel's first few pages strike up the keynote. Bertram's perception of his neighbor on the plane introduces him as a man quick to reach his own unproven conclusions about others: he compares her body to a scaffolding blocking the view through the window and decides her double chin must be well-licked in an active sex life. A general sense of uneasiness, sickness and violence supersedes Bertram's feelings of guilt about his long absence. Many elements suggest a wounded world: the bleeding sunlight, the swimmers' severed heads, the first airport runway, a "curved gash opened up with the blunt edge of a knife" (10, emphasis added). A sense of fake unity is another strong image embodied in the mountains which "posed as though in a family group" (11, emphasis added). The heat is felt to confine the newcomer, to enclose him in his own perspiration. ${ }^{11}$ Nothing authorizes the optimistic grandiloquence of the signs in the airport lobby and the roadside sights from the taxi; rural poverty and squalor make the island seem far removed from the Eden the Garvey epigraph conjures up. Later, Lonnie's diatribe mixes amusing details (such as the fire station burning down, car axles broken daily on potholes, typists who cannot type) with a scathing indictment of higher up citizens: a funeral director and a doctor who team up to open a rum distillery to bolster their businesses; and the smarter ones who went abroad to study and come back to "make money on the back of the people" (63). ${ }^{12}$

Assessing the characters' responses to life with respect to Garvey's recommendations discloses a fictional world precisely divided between the dominant and the dominated. Jackson personifies the dominant opportunist proud to announce he falls on his feet all the time while some others around him "keep landing on their arse" (66). He is the kind of man Garvey tells his audience to beware of and outsmart by exercising their minds. There is not a single redeeming trait in Jackson's character. When he tells Bertram of Dominic's fatal accident when he was run over by an unidentified automobile, he shifts the conversation, before there is time to bat an eye, and brings up his "sideline" - selling Japanese cars built in the United States. Bar tender Lonnie clearly

10. Garvey was most successful in terms of local action in the Caribbean after his release from prison and deportation. Back in Jamaica, he failed to be elected to the colonial legislature but launched the first-ever political party for Black people that ultimately led to the creation of trade unions and local movements that sparked self-government and later independence. Of course, this trend spread from Jamaica to the other islands.

11. Here is the first allusion to the disturbing smell he carries about him, the need to wash... with the pump's rusty water outside... and the shirt he does not know what to do with and finally stuffs out of sight in a paper bag.

12. That A State of Independence "earned Phillips some antagonism from the Kittitian authorities" (Ledent 40) is easy to understand. The early description is unrelentingly critical and the taxi driver wonders whether his part-English customer is speaking out of embarrassment or disappointment: " [ ... ] it was impossible for Bertram to ignore the existence of a conflict between the optimism of this imminent independence, and the outward signs of a village still struggling to acquire the means to meet the most basic needs, such as running water and proper lighting. He wondered if he was suffering from those same feelings of liberal guilt that he had always despised in some English people, or if in fact his thoughts did contain astute insights into the current state of the island" (19). 
despises his most regular customer who, before turning his coat, liked to go by the name of Jackson X. To Lonnie, the island is a mere prostitute country, "just lifting our skirts to anybody with cash" (132). In the foreword to The European Tribe, Phillips speaks out about the supremacy of the United States, pointing out that Europe has become "little more than a cultural outpost of North America lapping up satellite television and Euro-Disney with glee" (x). ${ }^{13}$ Jackson, the American-friendly "Deputy Prime Minister, Minister of Agriculture, Lands, Housing, Labor and Tourism” (108), reigns proud of his power and demands his reserved table in the Ocean Front Bar. His referring to Bertram as a piece of flotsam brought by independence when they first are reunited is no innocent joke. Indeed, he later insults him in earnest when, swollen-headed, he tells Bertram he has no time to look into his plans because he is busy with "the work of history" (135). Jackson's character is so extreme he is a caricature of Garvey's dominant men who "understand the system and boss it" (Hill 806). He is not drunk on rum like the politician in the second epigraph (or on too many beers like Bertram), but on his sense of his own greatness. Bertram's character is likewise heavily lopsided on account of his (possibly exile-born) pride in thinking he can contribute to the new country's future. Furthermore, his language betrays the poverty of a mind that grinds the same idea again and again about a future on the island. When speaking with his mother about his past, his attempt to justify his falling out of touch comes out as a trite religious phrase that precludes a real need to explain and - mixing up tenses and times - takes refuge in the local language: "like I was born again and everything is fresh. But it's only today walking about Sandy Bay and Baytown that I can see that maybe I was born again the same fellar" (85). He, too, can be seen as a caricature: a spineless jellyfish that has sprung out of Garvey's dichotomous world.

No reader knows first-hand how characters are given their names. However, choices often invite conjecture, and this is true of Bertram's first name: did it arise from Lord Bertram, the absentee plantation owner in Jane Austen's Mansfield Park? ${ }^{14}$ If that is the case, a wealthy slave owner's name is attributed, ironically, to an insignificant descendant of slaves. Irony may also be etymological as Bertram means "brilliant raven" (Rule 188) - a bird that symbolized wisdom in Saxon mythology. Bertram is no bird free to fly in the open. On the contrary, he is the jellyfish Garvey anathematizes. He is the opposite of an ideal ambitious black man, enterprising, eager to learn, a doer pushing his life ahead independently of the powers that be. He is listless, anything but resilient. He feels superior, ${ }^{15}$ is critical of the ill-clad taxi driver, especially his trousers hanging at the crotch; but his remark on the old man's hands also alerts the reader to Bertram's weak nature soon to be revealed: the older man's gnarled hands and his limp suggest he has adapted to the situation, perhaps found a new occupation with the developing tourist trade, and moved up from some hard manual work that maimed him.

13. The same concern surfaces in A State of Independence: Bertram sees a worker linking homes with cable television bringing American programs to the islanders. He waves to the man courteously, a meaningless gesture, then turns away.

14. In Culture and Imperialism, Edward Said took issue with, to him, Jane Austen's skirting of colonial issues: "In time there would no longer be a dead silence when slavery was spoken of, and the subject became central to a new understanding of what Europe was" (96). Said's comments are impassioned. Jane Austen's irony is ignored, her well-known abolitionist feelings perhaps visible in the title she chose: Lord Mansfield's 1772 verdict opposed an owner's wish to have James Somersett returned to slavery in Virginia.

15. Bertram the returnee looks down upon the old man's taxi, a Ford Corsair, a relic of the past no longer seen on British roads. 
Bertram is not upwardly mobile. He is a follower, unassuming. Early on, although he knows better than to believe Jackson's pronouncement that the first plane to land on the island is a "clumsy piece of machinery" (11), he fails to confront the friend he is happy to bat for, and serves Jackson who is practicing his bowling until the sun goes down. Similarly, although he knows his mother is wrong not to take the younger Dominic to their father's funeral, he only weakly protests, fails to argue, by telling his mother of their attempt (which was Dominic's own idea) to visit him in the hospital. He was only a boy of eight at the time, of course, but this lack of resolution is symptomatic of the man he is to become... As a teenager, while everyone felt he would fail, he studies for the scholarship at the insistence of Father Daniels - not out of ambition. Indeed, he quickly capitulates after two years in Britain with the excuse he could not keep up with the course and did not want to become a lawyer anyway. The stark truth is that he constantly backs out of situations, any situation risking to "[make] his life unbearably complicated" (33).

Sexual involvement is a case in point. He is unsure of what is happening on the beach with his girlfriend Patsy. Young Patsy is the one who takes the lead. She tells him he is the one she wants, not Dominic, but has to urge him on: "Bertram, please do something or I going to take fright and leave this place" (36). In fact, he does nothing and his post-intercourse apathy is grotesquely out of joint, from head to toe. Feeling is absent, "his mind [was] turning over, his feet itching for he could feel the sand that had squeezed its way between shoe and sock" (37).

Limp-minded Bertram, now a returning adult, moves from reality instructor to reality instructor as the story unfolds. First the taxi driver he tries to lord over. The old man does not want to be rushed, stands his ground reminding Bertram he has come home, a place where people do not like to run. Secondly, his dream of opening a business independent of the white man (the move Garvey advocates) is derided by his mother who sees her son as just another Mr. Carter-to-be, selling meat peppered with flies, batteries in the cricket season and beer up the ghaut. Thirdly, Jackson, who wants to humiliate him for his own reasons, ${ }^{16}$ calls him a "raggedy-arse boy" (113) and advises him to go back where he comes from. Finally, in kinder but ironical terms, Patsy parodies his independent businessman's wish:

“... a big house down by the beach, a house bigger than anyone ever built before, isn't it?"

Bertram was annoyed but he said nothing. Patsy twisted around so she now faced him, then carried on.

"But that will be after you open up the black man's business that bound to make you come a millionaire in a few weeks at the most." (141)

Though “annoyed," he says nothing. Weak-kneed Bertram's behavior invites the reader to paraphrase, or parody, Garvey by turning his sentence around: While Garvey said, "Your country can be no greater than yourselves" (epigraph), Bertram remains no greater than his country. He still has made no decision as the story is about to wind up. He is shown grinding his spittle into the tarmac with the tip of his shoe. Can this be read as a useless British reflex regarding cleanliness, or a way to erase his presence and run away from the question weighing on his mind? He still is a milksop trying to "imagine

16. Jackson failed to win the scholarship and is proud of his success. But, as a youth, he may have, like the fox in La Fontaine's fable, found the scholarship "too green," like the grapes it could not reach and eat. 
how he might cope were he to make his peace with his own mediocrity" (157). Grinding his spittle does not help him make a decision, as the modal verbs below point out: "[he] walked on and wondered if later this same day he should ask Mrs. Sutton how he might help his mother" (158, emphasis added). He needs to lean on someone. Mrs. Sutton is the ideal person, a strong woman, his former Sunday school teacher.

Bertram is condemned to smallness. Livingstone, his as yet unacknowledged son, feels cramped on the island, "Too small in size and too small in the head" (103). Bertram himself had left for Britain in the past, though unaware of his reasons. Livingstone is already Americanized with his Japanese wrist watch and sheened hair-do. He is mentally ready to leave as his grandfather, Bertram's father, did; and as Patsy's parents did when they emigrated to Canada, abandoning their daughter to be raised by her ailing aunt. The new world is where the life is, Livingstone says. But the island's smallness is not tragic all the way. Bertram has a self-derogatory thought on seeing Princess Margaret's car speeding between bystanders: it occurs to him the driver should apply the brakes before the car plunges into the sea at the "far end of the island" (138). The wording would be fine without the epithet "far"... but its presence suggests a joke on an island where nothing is far.

This humorous touch, as well as the smallness in the head, invites the reader to look beyond Garvey's race-oriented address and the matter of independence from the former colonial power, in order to consider the incidence of an existential substratum.

Limits, isolation, are present in an islander's mental outlook - whether as an asset or a liability. Bertram feels the "claustrophobia" of the heat after deplaning. An oxymoron, the "fur-soft grip of the Caribbean night" (48) later seals up this negative impression. The island is a prison. The self also is a prison. Each of the several characters behaves and thinks as if he or she were confined in a room of his own. The book's cover illustration, lush vegetation, is devoid of human presence or activity. There must be people living behind the neat curtains of the better cement home, and others in the smaller and paltry-looking boarded shack. The windows are dark, the doors closed. The characters live side by side rather than together. Only briefly is there a relationship between Bertram and Dominic. The fatherless boys are walled together outside their family: their absent father is reduced to his progenitor's function; Bertram does not even know his father's first name, something that might have given them a chance to see him in hospital. The brothers who used to be constant companions in their youth, played, worked, ate, slept together (and who even lost their virginity on the same day with the same girl) become estranged when Patsy gives herself to Bertram, who pleads with Dominic that he did not plan anything. Bertram's departure for England signals the end of the brothers' fragile togetherness. Dominic is the one who perseveres in writing but communication dries up, "like a river bed in summer" (26). The image suggests their separation was as unavoidable as mother nature's work in dry weather. That now dead relationship is not replaced by any new one. There is nothing in sex for Bertram. It is physical, mechanical an embarrassment as Patsy slowly helps him "break into a thick milky predicament" (37). Patsy has her way; Bertram remains absent, uncaring. And his words are unbelievably rude when he later argues he cannot bring her to Britain, like an "extra baggage" (96).

No one seems to be aware of, let alone mind, isolation. Bertram's mother protracts her old age solitude when she puts him out. She has every reason to be bitter after being 
forgotten, ignored, for twenty years, but she objectively might need her son's care. But she allows her hurt feelings to get the better of her. Patsy later reveals to Bertram that she also pushed Dominic out of her life for philandering with a married woman:

The two of them mash up when your mother catch him in her house winding with a next man's wife. So Dominic left to stay up town where he start to hit the liquor so hard people begin calling Bacchus Francis. He almost certainly fell out of the factory and under the car so don't feel no guilt, you hear me. (143)

Patsy's advice comes too late for Bertram: his mother had already taken a full revenge by hiding Dominic's death from him. She had played a cruel game, cruel to herself and cruel to Bertram when she told him Dominic was probably waiting by the gate and would soon be in.

The feeling of rampant unrelatedness between mother and sons is echoed in many other elements in the course of the story. Absence to the others is general. The "drinkinfested chatter" heard at the bayfront is a strong case in point: "These men listened to themselves talking, then burst out laughing and took another drink. But their conversation led nowhere." (131) The novel is tightly constructed. Isolation and estrangement find an echo even in the typography. There are no transitions from scene to scene. The most blatant instance of this occurs when Bertram's first meeting with Jackson ends abruptly. The text discreetly underlines the chasm between them: "Then they both continued their meal as though strangers" (68). Then, two blank lines later, the reader finds Bertram in the churchyard where his brother is buried. Lack of unity also prevails there. The churchyard is described as littering the hillside where "the many tablets of stone were of variable and independent design" (69). ${ }^{17}$ No dates are engraved upon Dominic's plain slab: just the name of a defunct individual who slipped in and out of the world unnoticed, another transparent jellyfish - better dead than alive according to Garvey.

What I feel like calling the islandization of the characters is hauntingly present in the inane assertion Bertram bubbles up to Lonnie who, incidentally has just, out of the blue, told a customer whom he hardly knows his reason for remaining single:

"And how you find England? Cold, I bet."

"Cold for sure," said Bertram. "But it has its benefits. Plenty of black people there so you never really getting out of touch.” (62)

Following this caustic moment when Bertram's adopted Britishness ${ }^{18}$ surfaces under a varnish of Caribbean syntax, the need for togetherness is underlined when Bertram encounters charitable Mrs. Sutton who has come to help his mother. The old lady asks him to take her back to her house up the ghaut. She takes his arm, then unhooks her arm as if to emphasize her surprise about Bertram's ignorance of Dominic's death, hooks it back into his, brings up Bertram's possibly leaving the island again - her very words are "slinging your hook again" - and finally unbitches herself from Bertram at the top of the ghaut (80-1). The choice of that final verb (unhook might have been used to pursue

17. The layout of Baytown offers another instance of jumbled buildings, commercial outlets or government offices; dwellings strewn like pebbles on the sand, entangled slums, a helter-skelter street pattern (see p. 57). The Royal Hotel (probably built with American funds) is the only well-ordered place.

18. Bertram is pathetic parodying himself in the role of the returnee comfortable with his life overseas. As if there was no discrimination, no racial tensions in a country where anger, in Notting Hill (1976) and Bristol (1980) for instance, erupted in violence. Such major riots are necessarily part of Bertram's consciousness. 
the metaphor) suggests that Bertram feels uncomfortable, not just for pulling the old woman, draft horse like, but with her mildly worded reproachful discourse. Only when Mrs. Sutton is about to open her door does Bertram recall that he should have asked her news of her husband. He is, as usual, engrossed in his own predicament and oblivious of others. When he returns to his mother's bedside, the finishing touch of that passage is her slipping "her hand out of his" (84), and her telling him he is not welcome in her home. Hesitant and uncertain, Bertram stalls for time: he will leave after the celebration of independence. Does he hope the break is not final?

Where can he go? Patsy ${ }^{19}$ welcomes him back. Will he stay with her? Patsy no longer is an attractive youth with firm breasts. To her question whether he may be expected in Britain, he answers "its just about finish" (149, emphasis added). Whoever that person is, perhaps now a mother, or his current lover, she is no more than a neutral pronoun standing for relationship or affair. Another piece of luggage is what comes to mind as he speaks. So, he may selfishly remain on the island for Patsy to take care of him. Although some feeling at last comes to him, there still is a dividing force between them:

His body stiffened, its interior framework collapsed, and all his emotional and structural strength was drained away as if her soft female hand had wrenched the plug of his masculinity.

When Bertram woke up they were teaspooned together, a thin film of sweat both holding and dividing them. (147)

Delving into the characters' lives from Bertram's return to the pandemonium of the (wet) independence celebration brings out a bleak vision of mankind. Many questions remain unanswered in the text, as the hands-off omniscient narrator leaves room for the reader to flesh out the characters.

Reading A State of Independence as a parody of Garvey's outmoded race-oriented address, or else of the wishful thinking of the signs in the airport is a possibility. There is no sign of a promising future. Soon to be independent from colonial power, but already dependent upon American dollars, the island is a tiny place between two big brothers. Garvey's speech is full of a God that is very much absent in the novel. The children go to Sunday school where they are taught by strict Mrs. Sutton. But there is no follow-up in adult lives. Religion plays no part in the people's lives, a point discreetly made when the reader is told the chair Bertram sits on in his mother's home only offers "religious discomfort" (27). Garvey exhorts his audience to spend "a little less on food and a little more on [their] brain" (Hill 809). In A State of Independence, food is described as a "stomach liner in order that more drink could be consumed" (58). Independence bingedrinking leaves people who were unable to find their way home lying by the roadside the morning after. The future of the independent island, or, rather, newly dependent, is bleak. Children wear uniforms to school, but rags on the street; celebration T-shirts issued free, but go barefoot, sometimes with only one shoe on. Women sweat behind their stoves while their men play dominoes. Cane cutters stagger home with exhaustion at the end of the day. All-round exploitation will continue.

19. Patricia, the "noble one" (Rule 100), is also self-centered in so far as her attachment to her adolescent love persists. One must understand no one wanted her, an unmarried mother, a "mule" (144), after Bertram "spoiled" (95) her. But her continued infatuation betrays a jealous feeling twenty years later: "I see somebody must be looking after you, but your neck is too high to wear collarless shirts" (91) she tells him after her initial surprise that he is back. 
Fictions follow their own logic. They do not impose a truth but only propose a not unlikely world left open to interpretation. The island's social make-up may not be as disastrous as Lonnie's unequivocal representation has it. Readers have to find their way, form an opinion from their own constructs. As Jean-Marie Schaeffer argues in Pourquoi la fiction ?, basing his remark on Plato's stance against mimetism, "[...] the autonomy of the ability to imagine as a specific mental activity must be admitted as well as the autonomy of playing with mimetic processes" $(41){ }^{20}$ So, beyond independence, beyond Garvey, perhaps A State of Independence reaches into another persuasion, both racial and existential.

At the end of The European Tribe, the fifteen essays that describe his travels as a black man in today's Europe but that also delve into the past - trying to figure Othello's life in Venice, thinking about the centuries of Moorish civilization in Spain, the rewriting of Soviet history, etc. - Phillips writes: "Europe must begin to restructure the tissue of lies that continues to be taught and digested at school and at home for we, black people, are an inextricable part of this small continent." (129, emphasis added). If we substitute "the world" for Europe and "small world" for small continent (as the United States has become part of the equation), this quotation from The European Tribe fits our reading of $A$ State of Independence by opening onto larger issues such as those Phillips raises. The novel is primarily a plea for the dignity of man. Life on the island does not give Bertram, or Dominic, or their mother - or even Jackson - a chance to become fine upstanding persons. Only Patsy is spared to a certain extent. She preserves her dignity as a no-longer-wanted lover, then as an unmarried mother but, twenty years later, she has only Bertram to turn to in that small place where she lives. She is dependent on a one-way relationship, condemned to insularity like Bertram. Patsy's situation can be projected upon the island: the now politically independent island faces another form of dependency.

Claude Julien

University François Rabelais, Tours

\section{Works Cited}

Frankin, John Hope. From Slavery to Freedom. New York: Knopf, 1988.

Garvey, Amy Jacques. Philosophy and Opinions of Marcus Garvey: or Africa for the Africans. New York: Routledge, 1986.

HiLl, Robert A. The Marcus Garvey and UNLA Papers. Vol. 1: 1826-Aug. 1919; Vol. 2: Nov. 1927-Aug. 1940. Berkeley: U of California P, 1990.

Ledent, Bénédicte. Caryl Phillips. Manchester: Manchester UP, 2002.

Philuips, Caryl. A State of Independence. London: Faber 1986.

—. The European Tribe. London: Picador, 1992.

Rule, Larevia. Name Your Baby. New York : Bantam, 1986.

SAID, Edward W. Culture and Imperialism. London : Vintage, 1994.

Schaeffer, Jean-Marie. Pourquoi la fiction? Paris : Seuil, 1999.

20. “[...] reconnaître l'autonomie de la capacité imaginative en tant qu'activité mentale spécifique, et donc aussi l'autonomie des processus mimétiques ludiques." 